\title{
Phenotypic matching in ovipositor size in the parasitoid Galeopsomyia sp. (Hymenoptera, Eulophidae) attacking different gall inducers
}

\author{
Fernando Albuquerque Luz' (i) , Ana Paula Moraes Goetz² (i) \& Milton de Souza Mendonça Jr. ${ }^{3}$ (D)
}

\begin{abstract}
1.Universidade Federal do Rio Grande do Sul, PPG-Ecologia, Instituto de Biociências, Porto Alegre, RS. Current address: Universidade Federal do Amazonas, Instituto de Saúde e Biotecnologia, Estrada Coari/Mamiá, 305, 69.460-000 Coari, AM, Brazil. (fernandoaluz@gmail.com)

2. Programa de Pós-Graduação em Biologia Animal, Universidade Federal do Rio Grande do Sul, Porto Alegre, RS, Brazil.(anapgoetz@gmail.com)

3.Universidade Federal do Rio Grande do Sul, Departamento de Ecologia, Instituto de Biociências, Porto Alegre, RS, Brazil. (milton.mendonca@ufrgs.br)
\end{abstract}

Received 11 September 2019

Accepted 22 April 2020

Published 05 June 2020

DOI $10.1590 / 1678-4766 e 2020008$

\begin{abstract}
Parasitoid ovipositor size importantly affects host choice; those attacking exposed hosts usually have shorter ovipositors compared to those needing drilling deeper through substrates such as plant tissue and gall tissue. Most studies treat this theme at the interspecific level, and the aim of this work was to test for intraspecific variation and phenotypic matching in ovipositor size for Galeopsomyia sp. attacking galls. Galls were sampled from Guapira opposita (Nyctaginaceae), a host plant to five species of Bruggmannia gallers (Diptera, Cecidomyiidae) in southern Brazil: Bruggmannia elongata, B. robusta, B. acaudata, and two undescribed species of Bruggmannia (sp. 1 and sp. 2). On forest transects, all galls from the 30 first galled plants found were sampled and kept in sealed plastic bags until parasitoid emergence. A total of 15 samples were done along two years. We measured galler last instar larvae length and gall thickness for each galling species, and ovipositor length for all Galeopsomyia sp. individuals emerging from the galls. There were no differences in larval length among galler species. However, Bruggmannia sp. 1 and sp. 2 galls were significantly thicker than those of $B$. acaudata, and the latter thicker than both B. elongata and B. robusta galls. Wasp ovipositor size differed significantly between those coming from Bruggmannia sp. 1 and sp. 2 galls relative to all others. Host extended phenotype size is thus fundamental to determine parasitoid size, but in this case host (larval) size does not change among species, although gall thickness was different. Thicker galls were attacked by larger parasitoids with longer ovipositors, denoting phenotypic matching. Thicker galls appear to be selecting larger parasitoid individuals, which in the long run can lead to important evolutionary change as well.
\end{abstract}

KEYWORDS. Bruggmannia, oviposition, host selection.

RESUMO. Acoplamento fenotípico no tamanho do ovipositor no parasitoide Galeopsomyia sp. (Hymenoptera, Eulophidae) atacando diferentes indutores de galhas. $\mathrm{O}$ tamanho do ovipositor dos parasitoides influencia a escolha do hospedeiro. Parasitoides que atacam hospedeiros expostos tendem a ter ovipositores menores em relação aos que precisam perfurar algum tipo de substratos ou tecidos como o das galhas. Como a maioria dos estudos trata esse assunto em nível interespecífico, o objetivo deste trabalho foi testar a variação intraespecífica e acoplamento fenotípico no tamanho do ovipositor de Galeopsomyia sp. no ataque a galhas. Foram amostradas galhas coletadas em Guapira opposita (Nyctaginaceae), planta hospedeira de cinco espécies de galhadores: Bruggmannia elongata, B. robusta, B. acaudatae duas espécies não descritas de Bruggmannia (sp. 1 e sp. 2 ) (Diptera, Cecidomyiidae). Em cada transecção, todas as galhas das 30 primeiras plantas encontradas foram coletadas e acondicionadas em saco plástico até a emergência dos parasitoides. Foram feitas 15 amostragens ao longo de dois anos. As larvas de último ínstar dos galhadores, espessura das galhas, assim como o tamanho do ovipositor dos indivíduos de Galeopsomyia sp. foram medidos. Não foi encontrada diferença para o tamanho das larvas entre espécies de galhador. Porém, as galhas de Bruggmannia sp. 1 e sp. 2 foram significativamente mais espessas que as de $B$. acaudata e essas mais espessas que as de B. elongata e B. robusta. Os tamanhos do ovipositor diferiram significativamente para vespas emergidas das galhas de Bruggmannia sp. $1 \mathrm{e} \mathrm{sp.}$ 2 em relação às demais. A dimensão do hospedeiro é fundamental para determinar o tamanho do parasitoide, mas neste caso o tamanho do hospedeiro não variou, e sim a espessura do tecido a ser perfurado. Galhas mais espessas foram atacadas por parasitoides maiores e com ovipositor mais longo, indicando acoplamento fenotípico. Assim, espessuras maiores de galha parecem estar selecionando indivíduos maiores da população, o que pode ter consequências evolutivas importantes a longo prazo.

PALAVRAS-CHAVE. Bruggmania, oviposição, seleção do hospedeiro.

The diversity of Hymenoptera parasites is partly the result of the wide variety of adaptations their ovipositors present, either in structure or in form (BoRING et al., 2009). Especifically, the increase in ovipositor length of the microhymenoptera is perhaps one of the keys for the great diversity of the group, because it made it possible to attack a large number of hosts of different sizes and occupying various spaces (Sivinski \& AlUJA, 2003). Thus, characteristics of the ovipositor, such as size and thickness, can be used to understand not only the way they attack or choose hosts (Boring et al., 2009), but also parasitoid life history, since ovipositor characteristics are a reflection of how the parasitoids reach and pierce their prey (PRICE, 1972).

Thus, evolution of the ovipositor is expected to be correlated with attributes (size, age, location) of the host that each parasitoid attacks (BRAJKOVIC et al., 1999), that is, the 
characteristics of the ovipositor are intimately linked to host type. Parasitoids that attack endophytic insects should be able to overcome the difficulty of perforating plant tissue, generating a phenotypic matching between parasitoid and host. In addition, the thickness of plant tissue can determine the availability and ease of finding hosts (WeIs, 1983; WeIS et al., 1985).

Among the endophytic insects, gall-inducers are the most diverse (Espírito-Santo \& Fernandes, 2007). These organisms are capable of inducing hyperplasia and/ or hypertrophy of plant tissue cells, resulting in the gall structure, which represents an extended phenotype of its inducer. Thus, each species of galler induces a unique form of gall on a plant species, with unique characteristics for each species pair (DREGER-JAUFRET \& SHORTHOUSE, 1992). Galling insects on their turn are attacked by a rich fauna of natural enemies and, according to BAILEY et al. (2009), the evolution of gall shape (size, thickness, external structures) is related to how much defense galls can provide against them. Among these enemies, the parasitoid Hymenoptera are the most significant ones, either as generalists or even species-specific (PrICE et al., 1986).

PRICE et al. (1987), when studying the adaptive nature of the galls, pointed out that galls having similar shapes would tend to share natural enemies (the enemy hypothesis). Thus, at the interspecific level, variations of the gall form may lead to phenotypic variations for natural enemies. It is expected that parasitoids exploring the same host would have similar ovipositor sizes (PRICE, 1972). However, this is not a rule, since it is common for species that attack the same host to differ in ovipositor length and this may be due to some hosts having no or low defense strategies and being easy to locate, ending up as targets for different parasitoids with different ovipositor sizes (PrICE, 1972).

In interactions with hosts protected by some kind of structure, such as galling insects, perforation of plant tissue is necessary, and the host will be attacked only by parasitoids with longer ovipositors (e.g. SIVINSKI et al., 2001). However, more recent studies have shown that parasitoids with short ovipositors may be able to attack galls at early stages of their development, where plant structure is still tender or slight, thus being able to "access" the larva (STONE \& SCHÖNROGGE, 2003; Rossi et al., 2006). The difference in ovipositor size may also vary intraspecifically, both due to the use of different hosts and across the geographical distribution of the parasitoid (BROWN \& ROSSI, 2013).

Few studies work with parasitoid intraspecific variations and the consequences of these variations for host use. Therefore, the aim of this paper was to study the variation in ovipositor size of the species Galeopsomyia sp. in relation to five different species of galling insects and their galls. Our hypothesis is that galls with different thickness will lead to differences in parasitoid ovipositor length, for example, thicker galls should result in parasitoid individuals with larger ovipositors.

\section{MATERIAL AND METHODS}

Study area. Samples were obtained from Santana Hill, Porto Alegre, Rio Grande do Sul, southern Brazil $\left(30^{\circ} 03^{\prime} 53.3^{\prime \prime} \mathrm{S}, 51^{\circ} 07^{\prime} 41.5^{\prime \prime} \mathrm{W}\right)$. This hill is a local hotspot of biological diversity, with fauna and flora biogeographically coming from different parts of the South American continent (GUERRA, 2003). It constitutes the highest point of the municipality of Porto Alegre, with $311 \mathrm{~m}$ of altitude. Its climate is subtropical, with hot summers. The hill has 1,000 ha of grasslands and forests. The forests represent an extension of the Atlantic Forest (Seasonal Forest), formed by vegetation characteristic of these plant formations, including species such as Nectandra appositifolia (Lauraceae), Sorocea bomplandii (Moraceae), Mollinedia elegans (Monimiaceae), and also Guapira opposita (Nyctaginaceae) (GuERRA, 2003).

Study system. Guapira opposita is a Nyctaginaceae species that occurs throughout Brazilian territory, characterized by a large degree of phenotypic plasticity (Souza \& LorenzI, 2008). This plant is known to be a super host for gallers, meaning that a large number of galling species of these herbivorous insects use it (a not unusual trend, e.g. OliveIra et al., 2013). Ecological studies with super hosts are interesting because they generate easier comparisons, with multiple gallers for a single, model plant species (Mendonça, 2007). In Rio Grande do Sul, according to Mendonça (2007), G. opposita can present up to seven different species of gallers.

Galeopsomyia Girault, 1916 is a genus belonging to Eulophidae, a very representative family among galling insect parasitoids, even being considered the most important in some systems, in the rare studies addressing the interaction between these organisms in Brazil (e.g. MaIA \& MonteIro, 1999; MAIA \& AZEVEDO, 2009), in addition, the genus has already been reported attacking G. opposita galls (MaIA \& AzEvEDO, 2009).

Sampling. Fifteen samples were carried out between March 2014 and February 2016, focusing on spring and summer months, when the study organisms were present. Galls of five inducing species were collected in G. opposita plants, all of them Cecidomyiidae belonging to genus Bruggmannia Tavares, 1906: B. elongata Maia \& Couri, 1992; B. robusta Maia \& Couri, 1992; B. acaudata Maia, 2004; Bruggmannia sp. 1; and Bruggmannia sp. 2 (the latter both new species for the literature according to V. C. Maia, Museu Nacional, UFRJ, Rio de Janeiro, Brazil).

Using preexisting trails inside the forest, in each of the samples a new transect is marked so as to not superpose with the previous one. Each transection was traversed in search for G. opposita with heights between $50 \mathrm{~cm}$ and 3 $\mathrm{m}$. The first 30 plants were inspected and all galls found were collected. After each sampling, galls were taken to the laboratory and wrapped in closed plastic bags. The galls exhibited simultaneous emergence of the parasitoids.

After emergence, wasps were individualized in $70 \%$ alcohol tubes. Ovipositor length and head width of the females $(\mathrm{n}=35)$ were measured in a stereomicroscope, 
this morphology should reflect a progenitor with similar characteristics, as hypothesized in other studies of the genus (e.g., Sivinski et al., 2001; Brown \& Rossi, 2013), that is, large wasp heads and ovipositors should mean large wasp mothers. Galls and larvae of the five species of gallers were also collected, and the last instar larvae of the gallers measured for length and greater width ( $\mathrm{n}=8$ for each species), all these larvae obtained in additional samples and also measured under a stereomicroscope with graduated ocular piece. The ratio between the larval length and width was used as a measure of shape. Galls were cut transversally and greater thickness was then measured ( $\mathrm{n}=9$ for each type of gall), from the outer wall of the gall to the larval chamber, where the larva was located. This would be the minimum distance that the parasitoid female ovipositor would need to drill to find the host, always taking into consideration the shortest possible span.

Data analysis. To test for differences between galler species for larval size, gall thickness and emerging parasitoid ovipositor length, ANOVA's with permutation implemented in the PASt software (HAMmER et al., 2001) were used. Subsequently, Tukey tests were carried out to compare eventual different gall thickness, larval dimensions and ovipositor sizes of parasitoids among hosts.

\section{RESULTS}

A total of 1,637 galls on G. opposita were sampled, divided among the five inducer species: B. elongata $(372$ galls); B. robusta (254); B. acaudata (128); Bruggmannia sp. 1 (756); Bruggmannia sp. 2 (127). Galeopsomyia sp. was the third most abundant species of parasitoid, totaling 75 specimens. Of these, 35 were females, which were used for ovipositor and head measurements. The females are distributed among gall morphotypes they originated from with the following abundance: Bruggmannia elongata (10 parasitoids); B. robusta (5); B. acaudata (6); Bruggmannia sp. 1 (5); Bruggmannia sp. 2 (9).

The last instar larvae of the five species of gallers had no significant differences in size among them $(F=0.929, p$ $=0.461$ ). All larvae ranged from $1.5-2.0 \mathrm{~mm}$ in length and 0.3-0.4 $\mathrm{mm}$ in width. As for the thickness from the outer gall wall to the larval chamber, the galls showed significant differences $(F=86.1 \mathrm{p}=0.001)$. B. elongata and B. robusta galls are less thick than $B$. acaudata ones and these three are less thick than Bruggmannia sp. 1 and Bruggmannia sp. 2 galls (Fig. 1), gall thickness varied from $0.6 \mathrm{~mm}$ to $3.6 \mathrm{~mm}$.

Female ovipositor size was strongly correlated with head size $\left(\mathrm{R}^{2}=0.88\right)$, so we used only ovipositor size in the analyses. Wasp ovipositor length ranged from $2.2 \mathrm{~mm}$ to $5.6 \mathrm{~mm}$, and differed significantly $(\mathrm{F}=4.825 ; \mathrm{p}=0.004)$ for individuals emerging from different galls. Females from the galls of B. elongata, B. robusta and B. acaudata have on average smaller ovipositors compared to those emerged from galls induced by Bruggmannia sp. 1 and Bruggmannia sp. 2 (Fig. 2).
Thicker galls were attacked by parasitoids with longer average ovipositors. Females with long ovipositors occurred in all galls, but more frequently in thicker ones. Females with short ovipositors occurred only in thinner galls.

\section{DISCUSSION}

Our data indicate that variation in ovipositor size allowed Galeopsomyia sp. to explore different gall thicknesses, since from the thicker galls emerged parasitoids with the longer ovipositors in the population. Taking into consideration that the offspring should reflect the size of the female mother which oviposited in that gall, we can theorize that smaller wasps are probably not able to oviposit in thicker galls. Studies indicate the existence of polymorphism in ovipositor size for several species of parasitoids (WESTEBERHARD, 2003), however, relating this variation to the way wasps explore different hosts is rare. This would potentially generate a form of phenotypic matching (ANDERSON et al., 2010), which in some ways implies that we do not clearly understand the ecological-evolutionary reasons for this polymorphism.

BROWN \& Rossi (2013) studied intraspecific variation in the ovipositor of Torymus umbilicatus (Hymenoptera, Torymidae) and associated the female ovipositor length plasticity with latitudinal factors, as well as finding a result similar to what we found here, where ovipositor size was influenced by shape and thickness of the host gall. LÀzLó \& TóTHMÉRÉSz (2013) demonstrated that gall size had no correlation with parasitoid community size or attack rate, but with length of the ovipositor needed to pierce the gall and reach the inductor larva. This corroborates our view of the functional morphology of the gall, evaluated here as tissue thickness to the larval chamber, but other aspects such as trichomes and hairs could be further evaluated in other studies. The results confirmed our initial hypothesis that the difference in gall thickness would influence the ovipositor size of females that hatch from that gall. The thicker galls had a concentration of individuals with long ovipositors, while less thick galls had not only wasps with shorter ovipositors but a diversity of ovipositor lengths - which prevents a proper phenotypic matching.

For WeIs et al. (1985), in a community, thicker galls limit parasitoid attack, however, this was not found in this study, where the parasitism rate of Galeopsomyia sp. was equivalent in the galls of different species of gallers, taking into account their abundances. However, this parasitoid may be specific to these hosts, which have specific interaction only with this species of plant, and are not found attacking any other of the galling species studied in the region for parasitoids in our lab (F. Luz, A. P. Goetz, and C. Prauchner, pers. obs., LabEcoInt, UFRGS).

Another factor that could influence parasitoid size and probably ovipositor length is host size (galler larvae), because larger galler larvae could harbor larger wasp larvae from which larger parasitoids would emerge (COHEN et al., 2005). This factor was discarded here, as the larvae of the five 
1

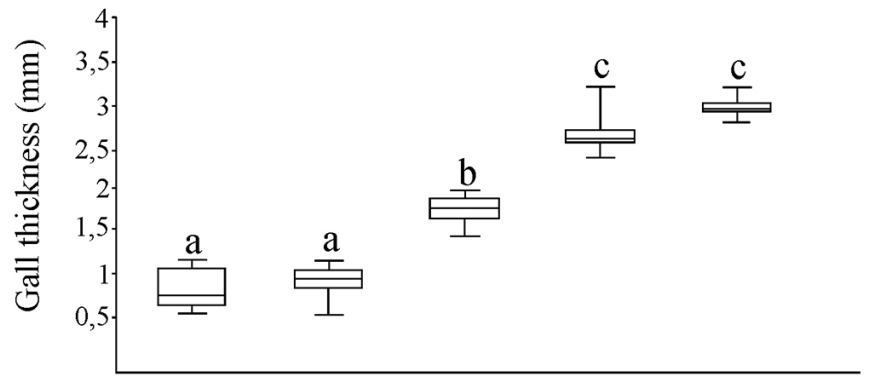

2

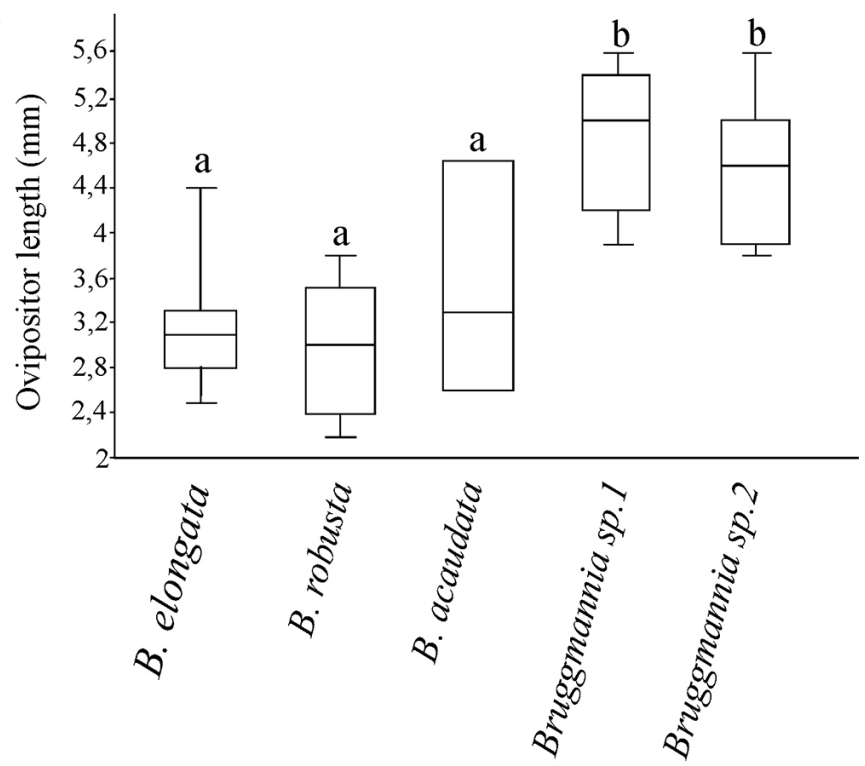

Figs 1, 2. Phenotic matching between the parasitoid Galeopsomyia sp. (Eulophidae) and its galling hosts, five species of Bruggmania (Cecidomyiidae, B. elongata, B. robusta, B. acaudata, and Bruggmania sp. 1 and sp. 2) in Guapira opposita (Nyctaginaceae): Fig. 1, gall thickness (dimension between the outer wall of the gall and the larval chamber); Fig. 2, female ovipositor length of parasitoid in the different hosts.

hosts did not present size/shape differences. It is important to point out, however, that we could not evaluate whether the parasitoid also consumed gall resources directly (as for example Rileya sp. larvae seem to do in Eugeniamyia dispar galls, Mendonça \& Romanowski, 2002), which could also generate an increase in parasitoid size, and consequently on its ovipositor size.

A galler defense strategy, besides investing in thickness and size of the gall (GoDFRAY, 1994), is plant tissue toughness, which is usually associated to gall development along time, since some freshly induced galls tend to be harder (FERNANDES et al., 1999). This factor was not evaluated in the present study, since hardness could decrease parasitism rate but probably did not select for ovipositor length.

Parasitoids do not necessarily prefer certain hosts "per se", and a first preference may be habitat-based (or also specific conditions of humidity, temperature, luminosity). Moreover, another determinant factor in parasitoid attack are plant cues, because the galler host plant may serve as the first recognition step for the site where this parasitoid may oviposit (GODFRAY, 1994). Thus, many of these parasitoids can attack different insects that feed on only one plant (VINSON, 1976), and this may be one of the reasons why Galeopsomyia sp. attacks different hosts in G. opposita.

Gallers of the same genus attacking $G$. opposita may have speciated sympatrically on the same host plant, as already suggested by JOY \& CRESPI (2007) when studying a similar system. In a setting like this, ancestor taxa of Galeopsomyia sp. may have been historically associated with this plant and galling ancestors of the current Bruggmannia. Selective pressures, such as these apparently imposed by the morphology of galls on individuals of the parasitoid population, may also lead to speciation, as suggested by BROWN \& Rossi (2013) in a similar study.

Thus, we conclude that gall thickness selects phenotypes in this Galeopsomyia sp. population, because wasps with longer ovipositors are able to attack all hosts, while the shorter ones would attack only the less thick galls. This may have consequences related to ecological and evolutionary factors, such as variation in resource availability, changes in the genetic structure of the population of these wasps and, more dramatically, a probable future speciation in case of continued allopatry of the gallers in multiple sites, in a hypothetical coevolutionary mosaic (sensu THOMPSON, 2005). 
Acknowledgments. To Valéria Cid Maia (Museu Nacional, RJ) for galler identification; Nelson Perioto (Embrapa - Ribeirão Preto, SP) for parasitoid identification. To Simone Mundstock Jahnke, Geraldo Luiz Gonçalves Soares (Universidade Federal do Rio Grande do Sul) and Walter Santos de Araújo (Universidade Estadual de Montes Claros) for contributions to a previous version of this draft. To CAPES for a PhD scholarship to the first author, to CNPq for a productivity grant to the third author (309616/2015-8).

\section{REFERENCES}

Anderson, B.; Terblanche, J. S. \& Ellis, A. G. 2010. Predictable patterns of trait mismatches between interacting plants and insects. BMC Evolutionary Biology10:204.

Bailey, R.; Schönrogge, K.; CoOK, J. M.; Melika, G.; CsóKa, G.; Thuróczy, C. \& Stone, G. N. 2009. Host niches and defensive extended phenotypes structure parasitoid wasp communities. PLoS Biology 7:e1000179. https://doi.org/10.1371/journal.pbio.1000179.

Boring, C. A.; Sharkey, M. J. \& NychKa, J. A. 2009. Structure and Functional Morphology of the Ovipositor of Homolobus truncator (Hymenoptera: Ichneumonoidea: Braconidae). Journal of Hymenoptera Research 18:1-24.

Brajkovic, M.; Krunic, M.; Tomanovic, Z. \& Stanisavljevic, L. J. 1999. Morphological adaptations of the ovipositor of braconid wasps (Braconidae: Hymenoptera) associated to biological characteristics of their hosts. Acta Entomologica Serbica4:107-125.

Brown, P. \& Rossi, A. M. 2013. Geographic and Host-Associated Size Variation in the Parasitoid Wasp Torymus umbilicatus (Hymenoptera: Torymidae) in Florida: Implications for Host Survival and Community Structure. Florida Entomologist 96:832-838.

Cohen, J. E.; Jonsson, T.; Müller, C. B.; Godfray, H. C. \&Savage, V. M. 2005. Body sizes of hosts and parasitoids in individual feeding relationships. PNAS102:684-689. https://doi.org/10.1073/ pnas. 0408780102 .

Dreger-Jauffret, F. \& Shorthouse, J. D. 1992 Diversity of gall-inducing insects andtheir galls. In: SHORTHOUSE, J. D. \& ROHFRITSCH, O. eds. Biology of Insect-induced galls. New York, Oxford University Press, p. 8-33.

Esfírito-Santo, M. M. \& Fernandes, G. W. 2007. How many species of gall-inducing insects are there on earth, and where are they? Annals Entomological Society of America100(2):95-100.

Fernandes, G. W.; EsPírito-SANTO, M. M. \& FARIA, M. L. 1999.Cynipid gall growth dynamics and enemy attack: effects of gall size, toughness and thickness. Anais da Sociedade Entomológica do Brasil 28:211-281.

GodfraY, H. C. J. 1994. Parasitoids behavioral and evolutionary ecology. Princeton, Princeton University Press. 473p.

Guerra, T. 2003. Dossiê Morro Santana: Comissão de Instalação da Futura Unidade de Conservação da UFRGS. Porto Alegre, Editora UFRGS. 39p.

Hammer, Ø.; Harper, D. A. T \& Ryan, P. D. 2001. PAST: Paleontological statistics software package for education and data analysis. Palaeontologia Electronica 4:1-9.

Joy, J. B. \& CresPI, B. J. 2007. Adaptive radiation of gall-inducing insects within a single host-plant species. Evolution 61:784-795.
LÁszLó, Z. \& Tóthмérész, B. 2013. The enemy hypothesis: Correlates of gall morphology with parasitoid attack rates in two closely related rose cynipid galls. Bulletin of Entomological Research 103:326-335. https://doi.org/10.1017/S0007485312000764

MaIA, V. C. \&AzEvedo, M. A. P. 2009. Diversidade de micro-himenópteros associados com galhas de Cecidomyiidae (Diptera) em restingas do estado do Rio de Janeiro (Brasil). Biota Neotropica 9:151-164.

Maia, V. C. \& Monteiro, R. F. 1999. Espécies cecidógenas (Diptera, Cecidomyiidae) e parasitóides (Hymenoptera) associados a Guapira opposita (Vell.) Reitz. (Nyctaginaceae) na restinga da Barra de Maricá, Rio de Janeiro. Revista Brasileira deZoologia 16:483-487.

MendONÇA, M. DE S. JR. 2007. Plant diversity and galling arthropod diversity searching for taxonomic patterns in an animal-plant interaction in the Neotropics. Boletín de la Sociedad Argentina de Botanica 42:347-357.

MendonÇA, M. DE S. JR \& RomanowsKi, H. P. 2002.Natural enemies of the gall-maker Eugeniamyia dispar (Diptera, Cecidomyiidae): predatory ants and parasitoids. Brazilian Journal of Biology 62:269-275.

Oliveira, D. C.; Mendonça, Jr, M. S.; Moreira, A. S. F. P.; LemosFilho, J. P \& IsAias, R. M. S. 2013.Water stress and phenological synchronism between Copaifera langsdorffii (Fabaceae) and multiple galling insects: formation of seasonal patterns. Journal of Plant Interactions 8(3):225-233.

Price, P. W. 1972. Parasitoids utilizing same host - Adaptive nature of differences in size and form. Ecology 53:190-195.

Price, P. W.; Fernandes, G. W. \& Waring, G. L. 1987. Adaptative nature of insect galls. Environmental Entomology 16:15-24.

Price, P. W.; Westoby, M.; Rice, B.; Atsatt, P. R.; Fritz, R. S.; Thompson, J. N. \& Mobley, K. 1986. Parasite mediation in ecological interactions. Annual Review of Ecology and Systematics 17:487-505.

Rossi, A. M.; MurraY, M.; Hughes, K.; Kotowski, M.; Moon, D. C. \& STILING, P. 2006. Non-random distribution among a guild of parasitoids: Implications for community structure and host survival. Ecological Entomology 31:557-563.

Sivinski, J. \& Aluja, M. 2003. The evolution of ovipositor length in the parasitic Hymenoptera and the search for predictability in biological control. Florida Entomologist 86:143-150.

Sivinski, J.; VUlineC, K. \& AluJA, M. 2001.Ovipositor length in a guild of parasitoids (Hymenoptera: Braconidae) attacking Anastrepha spp. fruit flies (Diptera: Tephritidae) in Southern Mexico. Annals of the Entomological Society of America 94:886-895.

SouZA, V. C. \& LoRENZI, H. 2008. Botânica sistemática: guia ilustrado para identificação das famílias de Fanerógamas nativas e exóticas no Brasil, baseado em APG II. Nova Odessa, Instituto Plantarum. 703p.

StONE, G. N. \& SCHÖNROGGE, K. 2003. The adaptive significance of insect gall morphology. Trends in Ecology and Evolution 18:512-522.

Thompson, J. N. 2005.The geographic mosaic of coevolution. Chicago, University of Chicago Press. 443p.

VINSON, S. B. 1976. Host selection by insect parasitoids. Annual Review of Entomology 21:109-133.

WeIs, A. E. 1983. Patterns of parasitism by Torymus capite on hosts distributed in small patches. Journal of Animal Ecology 52:867-877.

Weis, A. E.; Abrahamson, W. G.\& McCrea, K. D.1985. Host gall size and oviposition success by the parasitoid Eurytoma gigantea. Ecological Entomology 10:341-348.

West-Eberhard, M. J.2003. Developmental Plasticity and Evolution. New York, Oxford University Press. 794p. 